\title{
„EKSTAZA” CZY „ADMIRACJA”? IKONOGRAFIA OBRAZU ŚW. FRANCISZKA Z MUZEUM DIECEZJALNEGO W SIEDLCACH W KONTEKŚCIE WYMOWY WYBRANYCH PŁÓCIEN Z SERII FRANCISZKAŃSKIEJ EL GRECA
}

\begin{abstract}
The widely adopted title of "Ecstasy of St Francis", a painting at the Diocesan Museum in Siedlce, was introduced in literature in 1966 based on the typology developed by José Gudiol. The designation continues to be used until today. However, the significance and the purport of the title has not been confronted with the representation, especially given the current knowledge about its details. No attention has been paid so far to the nature of the stigmata, nor have any conclusions been drawn from the arrangement of the fingers or the depiction of bone remains, their pattern and placement. An analysis of those motifs changes the previous interpretation of what the work seeks to convey. The paper also cites arguments in favour of amending the current dating, from 1578-80 to the early seventeenth century.
\end{abstract}

\section{Keywords}

El Greco, "Ecstasy of St Francis", notions of "ecstasy" and "admiration", symbolism of the open arms gesture, stigmata and finger arrangement, context of the skull and bone fragments, painting conservation

Powszechnie przyjęła się nazwa „Ekstaza św. Franciszka” dla obrazu z Muzeum Diecezjalnego w Siedlcach, sygnowanego autografem El Greca (il.1)1. W pierw-

${ }^{1}$ Siedlce, Muzeum Diecezjalne, Olej na płótnie: $102 \times 75 \mathrm{~cm}$. Przedmiotowy artykuł powstał w 2019 r. i 8 lutego został skierowany do „Biuletynu Historii Sztuki”. Sekretarz redakcji Marta Bo- 


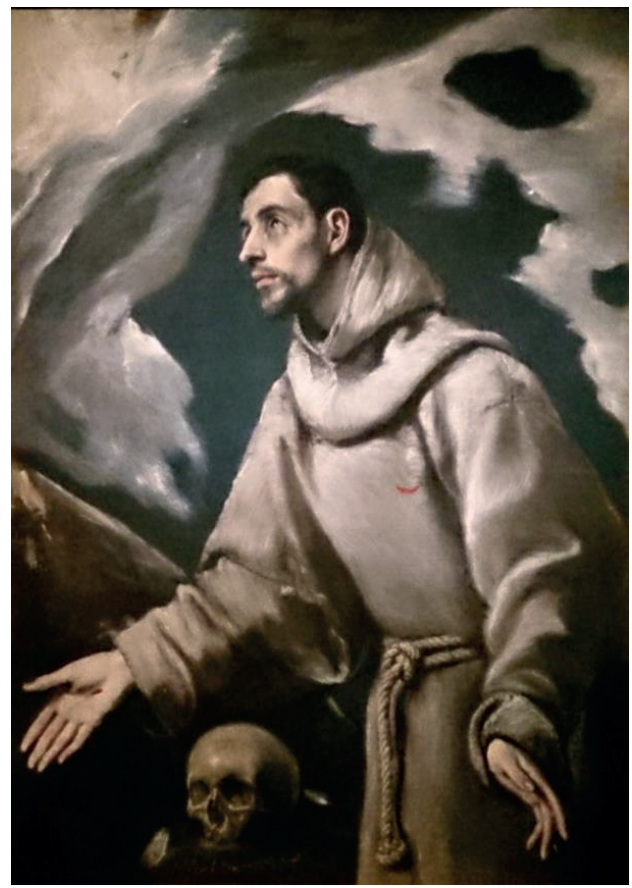

1. El Greco, Admiracja św. Franciszka, zw. dotychczas Ekstaza św. Franciszka. Stan z 2016 r. (przed konserwacją w MNK). Siedlce, Muzeum Diecezjalne. Fot. autor.

szej publikacji z 1965 r. nie została użyta². Wprowadzona została w kolejnej pracy, w akapicie prezentującym tematykę dzieła - „Obraz ten przedstawia ekstazę św. Franciszka z Asyżu po otrzymaniu stygmatów (il.1)"3 - podpis zaś pod ilustracją jednoznacznie określił nasze dzieło: „El Greco (?), Ekstaza św. Franciszka”4. Autor-

berska przez 10 miesięcy nie skierowała go do recenzji zewnętrznych. Wielokrotnie monitowana, 12 grudnia 2019 r. odmówiła dalszej współpracy. Konflikt interesów i naciski w środowisku historyków sztuki spowodowały odmowę druku w czasopiśmie „Modus. Prace z Historii Sztuki” i w „Roczniku Historii Sztuki”. Szczególnie nieprzychylny publikacji był jeden z recenzentów, znany autorowi, zajmujący się przedmiotową problematyką.

2 Katalog zabytków sztuki w Polsce 1965, s. 7: „Na plebanii: obraz Św. Franciszka (fig. 22) warsztat El Greca, 4 ćw. w. XVI”. Tak samo podpisana została ilustracja. Jak wynika z listu Witalisa Wolnego do redakcji „Biuletynu Historii Sztuki”, także w zaginionej notatce wykonanej przez Bogusława Kopydłowskiego, który wstępnie inwentaryzował zabytki w powiecie sokołowskim w latach 1952-54, obraz został określony jako „Św. Franciszek”, zob. Wolny 2004, s. 431. Zaprzeczyły temu Galicka i Sygietyńska, twierdząc, że Kopydłowski ani słowem nie wspomniał o obrazie św. Franciszka z Kosowa, choć potwierdziły, że inwentaryzację przeprowadził a maszynopis był w redakcji Katalogu Zabytków Sztuki w Warszawie, por. Galicka, Sygietyńska 2005, s. 209.

${ }^{3}$ Galicka, Sygietyńska 1966, s. 340 oraz w podpisie pod il. 1.

${ }^{4}$ Ibidem, w podpisie pod il. 1. 
ki artykułu dostrzegły wprawdzie stygmaty ${ }^{5}$, ale zapoznały się także z pracą José Gudiola wydaną cztery lata wcześniej i na jej podstawie przeniosły na polski grunt użyte przezeń określenie jednego z typów serii franciszkańskiej mistrza z Toledo „Ecstasy of St. Francis”. Analizując obrazy, Gudiol usystematyzowal je ikonograficznie, wyodrębniając trzynaście rodzajów przedstawień świętego zakonnika. Pierwszy typ to „Stygmatyzacja św. Franciszka w obecności brata Leona”, drugi: „Św. Franciszek podczas modlitwy”, trzeci i czwarty o tej samej nazwie: „Stygmatyzacja św. Franciszka”, piąty: „Ekstaza św. Franciszka z widzeniem Ukrzyżowanego”, szósty: „Ekstaza św. Franciszka z ręką na piersi”, siódmy: „Modlitwa w jaskini św. Franciszka z bratem Leonem”, ósmy: „Stygmatyzacja św. Franciszka w obecności brata Leona”, dziewiąty: „Św. Franciszek rozważa nad śmiercią z bratem Leonem u jego stóp”, dziesiąty: „Modlitwa św. Franciszka przed krzyżem w jaskini”, jedenasty: „Medytacja św. Franciszka w jaskini”, dwunasty: „Św. Franciszek podczas modlitwy” i trzynasty: „Ekstaza św. Franciszka””. W artykule z 1966 r. o płótnie ujawnionym w Kosowie Lackim czytamy, że typy te „różnią się między sobą: stadiami cudownego epizodu (modlitwa, medytacja, stygmatyzacja, ekstaza), ilością atrybutów i anegdotycznych (sic!) akcesoriów, wreszcie upozowaniem ciała i gestów rąk"

Niefortunne zapożyczenie z języka angielskiego zdeterminowane zostało przyjętym na zachodzie nazewnictwem, niekwestionowanym w kraju i bezrefleksyjnie przeszczepionym do bogatego słowotwórczo oraz precyzyjnego języka polskiego. Raz użyty termin pozostał. Powtórzony został w kolejnej publikacji przybliżającej obraz ${ }^{9}$. Także na okolicznościowej wystawie Ars Sacra El Greca w Muzeum Diecezjalnym w Siedlcach, trwającej od 4 października 2018 do 13 stycznia 2019 r., płótno z kosowskiej plebanii tak właśnie zostało określone. Znaczenia i wymowy użytego tytułu nie skonfrontowano jednak $\mathrm{z}$ analizą przedstawienia, w szczególności w odniesieniu do teraźniejszej wiedzy na jego temat.

Ekstaza, ze starogreckiego ék $\kappa \tau \alpha \sigma \iota \varsigma$ (bycie na zewnątrz siebie), jest pojęciem wieloznacznym, odbiegającym także od pierwotnej etymologii znaczenia ${ }^{10}$. Wprawdzie rozumiana może być również jako mistyczne wyjście duszy z ciała w szczególnej chwili zjednoczenia z Bogiem, jednak na ogół łączona jest z głębią

${ }^{5}$ Ibidem, s. 340.

${ }^{6}$ Gudiol 1962, s. 203. Zob. także Wethey 1962.

7 Gudiol 1962, s. 196-203. Typy ikonograficzne przedstawień świętego przypomniał niedawno ks. Robert Mirończuk, zob. Mirończuk 2014a, s. 157-159. Idem 2014b, s. 78-79. Zob. także Grabski 2016, s. 103-120.

${ }^{8}$ Galicka, Sygietyńska 1966, s. 342.

9 Eaedem 2006, s. 147-160.

10 Zob.: Słownik języka polskiego 1965, s. 690. Słownik wyrazów obcych 1997, s. 280. Wielki słownik wyrazów obcych 2008, s. 240. 
doznań psychiczno-fizycznych, które ograniczają zdolność percepcji bodźców zewnętrznych. Pojęcie ekstazy kojarzy się zwłaszcza ze stanem przebywania w transie i z działaniem nieracjonalnym ${ }^{11}$. Stan ten osiągano długotrwałym tańcem przy odpowiedniej rytmice muzyki oraz zażywaniem substancji wspomagających jego wywołanie. W ekstazie tańczyły menady z orszaku Dionizosa wyobrażane w starożytnym malarstwie wazowym, który to motyw rozkwitł po wystawieniu tragedii Eurypidesa nawiązującej do religijnego mitu bachicznego. W twórczości nowożytnej temat ten podjął Tycjan w obrazie „Bachus i Ariadna”, namalowanym dla księcia Ferrary Alfonsa d'Este ${ }^{12}$. Kontynuatorem podobnych scen był Poussin, nieodwołujący się jednak do drastycznych elementów scenerii charakterystycznych dla Tycjana, czego przykładem jest sielskie wyobrażenie „Bachanaliów przed statuą Pana"13. Takim przedstawieniom termin ten odpowiada i z podobnymi jest kojarzony. W stany ekstatyczne wprowadzali się także szamani w celu połączenia się z zaświatami i duchami - co stanowi temat badany w antropologii kultury. Tego rodzaju postawy nie wypada odnosić do przedstawień św. Franciszka z obrazów El Greca, chociażby dlatego, że jego reakcje, mimo doświadczenia mistycznego, były racjonalne.

Wyraz twarzy zakonnika z obrazu w Muzeum Diecezjalnym w Siedlcach jest skupiony i poważny, a postać statyczna i niemal pomnikowa. Nie ma w sobie najmniejszego elementu ekstatycznego uniesienia. Wzrok wzniesiony ku górze i załzawienie lewego oka z kroplą łzy zawieszonej na dolnej powiece (il. 2) nie stanowią wystarczających przesłanek do zastosowania terminu „ekstaza”. Wzbierające łzy nie są skutkiem stygmatycznego bólu, lecz wynikają z uwielbienia Boga, z przemyśleń nad naturą wszechrzeczy. Nie jest przy tym istotne, kto był modelem - czy jeden

2. Wyraz twarzy św. Franciszka, detal obrazu. Fot. autor.

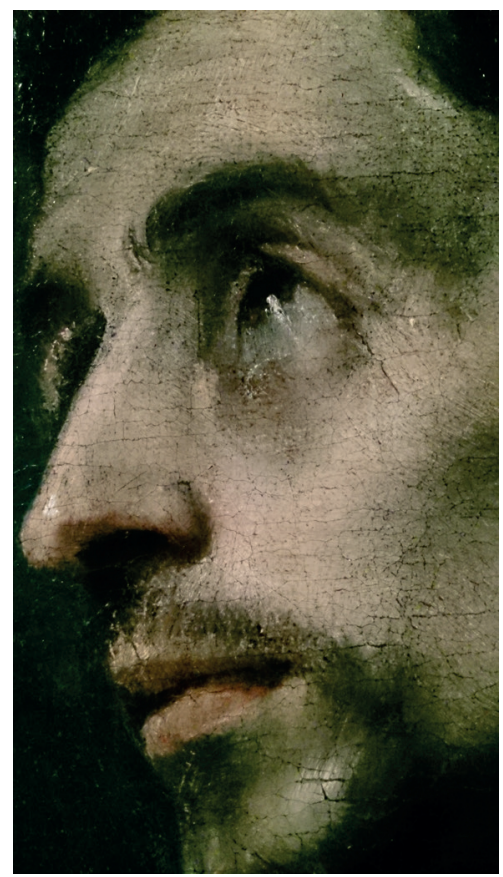

${ }^{11}$ Jest to widoczne w rozumieniu frazeologicznym, por. Skorupka 1985, s. 213: 1. Być w stanie ekstazy. 2. Działać pod wpływem ekstazy. 3. Popadać, wpadać w ekstazę. 4. Roztapiać się, tonąć, zatapiać się w ekstazie. 5. Budzić się z ekstazy.

${ }_{12}$ Londyn, National Gallery, NG35. Olej na płótnie: 176,5 × $191 \mathrm{~cm}$, ok. 1520-23.

${ }^{13}$ Londyn, National Gallery, NG62. Olej na płótnie: $98 \times 142,5$ cm, ok. 1631-33. 
z chorych umysłowo ze szpitala dla obłąkanych w Toledo, czy nie. Istotne jest, co wyraził artysta, jakie przesłanie przekazał widzowi. Ukierunkowanie spojrzenia i jego charakter wyrażają przekonanie o miłości Stwórcy do człowieka odwzajemnionej przez świętego i jednocześnie własnej znikomości i kruchości ziemskiej egzystencji oraz istoty miłosierdzia wobec współbraci. Zaświadcza o tym czaszka ludzka - symbol vanitas - kluczowy detal przedstawienia (il. 3). W bezpośredniej jej bliskości malarz schematycznie wyraził jasnymi plamami na ciemniejszym tle rozfragmentowane szczątki kostne. To w wyniku ich odkrycia św. Franciszek rozkłada ręce, wzrok wznosząc do nieba. Jest to motyw odbiegający od większości dotychczasowych przedstawień, w których samoistna czaszka spoczywa na skale ${ }^{14}$, co znaczy, że została przeniesiona i złożona na niej przez zakonnika. Tu wydaje się pozostawać nieopodal pierwotnego miejsca odkrycia, do którego mogło dojść wskutek erozji ziemi na stoku wzniesienia. Pozbawiona jest żuchwy. Kości szczęki są wyraźnie uszkodzone, również obrzeże jamy nosowej i delikatna przegroda w jej wnętrzu.

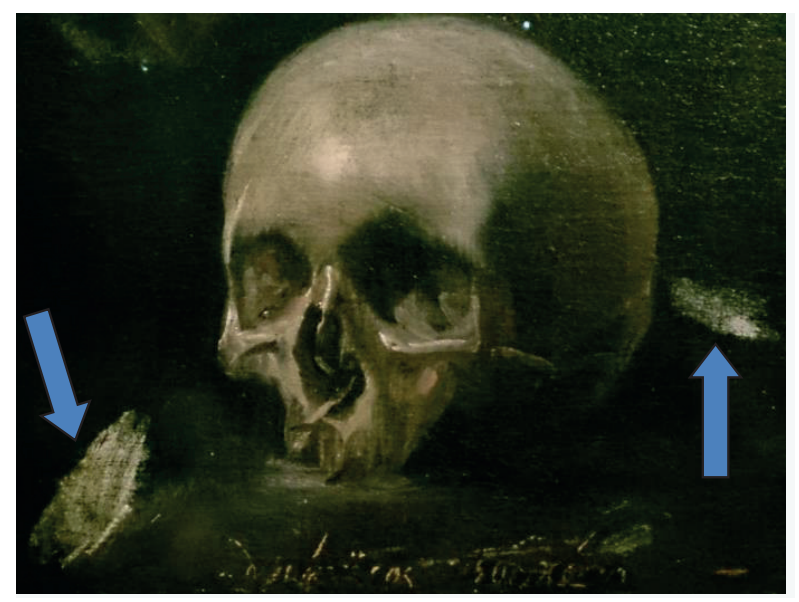

3. Czaszka ludzka i rozfragmentowane szczątki kostne (zaznaczone strzałkami) detal obrazu. Fot. autor.

Popularną kompozycją związaną z opisanym wyżej detalem była scena przedstawiająca medytację o śmierci podczas górskich rekolekcji. Prezentuje ją między innymi obraz „Św. Franciszek i brat Leon rozmyślają o śmierci” (San Francisco de Asís y el hermano León meditando sobre la Muerte, il. 5) ${ }^{15}$. El Greco w tym dziele stworzył jedną z najbardziej uderzających i oryginalnych scen, której wymiar tran-

14 Gudiol 1962, s. 203.

15 Ottawa, National Gallery of Canada, 4267. Olej na płótnie: 103,2 × 168 cm, 1600-1605 r. 
scendentalny zawiera tajemnica ludzkiej duszy ${ }^{16}$. Św. Franciszek, klęcząc na skraju jaskini, trzyma delikatnie w dłoniach czaszkę, a jego współbrat ze splecionymi do modlitwy dłońmi także wpatruje się w nią w skupieniu. W tle ziemisty stok wzniesienia uświadamia pewne realia i skłania do dopowiedzenia historii związanej z momentem poprzedzającym medytację. Nie ulega wątpliwości, że odkrycie było przypadkowe. Mnisi, spacerując, znaleźli się przy wejściu do jaskini, gdzie natknęli się na szczątki ludzkie odsłonięte w wyniku erozji stoku - najpewniej osunięcia się ziemi bądź wygrzebania kości przez dzikie zwierzęta z pierwotnego pochówku w grocie. Nie wydaje się, aby przynieśli tu czaszkę w celu medytacji. Na dłoni św. Franciszka widoczny jest stygmat, niemający bezpośredniego związku $\mathrm{z}$ adoracją Boga $\mathrm{w}$ tym momencie, czyli ze sceną przedstawienia. Cieszący się popularnością obraz znany jest $\mathrm{z}$ replik ${ }^{17}$.

$\mathrm{Na}$ obrazie z Kosowa nie jest widoczne miejsce, w które patrzy zakonnik. Nie są to rozświetlone obłoki w lewym górnym rogu płótna. Te bowiem, usytuowane ponad prawą skronią świętego, nie mogą stanowić dlań punktu odniesienia. Św. Franciszek łączy się z Absolutem, spoglądając gdzieś w dal, w niezaznaczone miejsce poza ramą obrazu. Aż tyle i tylko tyle ma doświadczyć widz. To zamierzony efekt malarza. Ciepła poświata w lewym górnym rogu dzieła na tle chłodnego nieba uświadamia widzowi boską obecność, z którą styczność ma święty, ale nie oglądający obraz. Poświata ta stanowi skraj blasku emanujący od Najwyższego. Św. Franciszek trzyma rozłożone ręce z otwartymi dłońmi w geście oddania się Bogu, uwielbienia Go, ale także w geście współczucia nad odkrytymi przezeń szczątkami człowieka. Rozwarcie ramion ma określone znaczenie symboliczne. Jest znakiem Miłosierdzia (Misericordia) w „Iconologii” u Cezarego Ripy, który pisze:

Lo stare con le braccia aperte, dinota che la Misericordia è à guisa di Giesù Christo Redentor nostro, chè la vera Misericordia, con prontezza c'aspetta sempre con le braccia aperte, per abbracciar tutti, e souuenir à le miserie nostre, \& Dante nel lib. 3. del Purgatorio sopra di ciò così dice:

Horribil furon li peccati miei

Ma la bontà infinita hà si gran braccie

Che prende ciò che si riuolge à lei ${ }^{18}$.

\footnotetext{
${ }_{16}$ Cuesta 2016, s. 242.

${ }_{17}$ Madryt, Museo Nacional del Prado, Pooo819. Pochodzenie: Museo de la Trinidad. Olej na płótnie: $103 \times 160,5$ cm, 1600-1614 r. Zob. Ruiz-Gómez 2007, s. 120-122.

${ }_{18}$ Ripa 1603, s. 329-330: „Rozwarte ramiona są znakiem, że Miłosierdzie naśladuje Jezusa Chrystusa, naszego Zbawiciela, który zawsze jest gotów z otwartymi ramionami przyjąć nas wszystkich i zaradzić naszym nędzom, o czym Dante w 3 Pieśni „Czyśćca” tak mówi: „Grzechy mię moje splamiły szkaradnie, / lecz Nieskończona Dobroć tak rozszerza / ramiona, iż w nie zbłąkany upadnie." (przekł. A. Świderska).
} 
Św. Franciszek nie pozostaje obojętny wobec odkrycia. Nie zostawia szczątków ludzkich samych sobie. Zwraca się do Stwórcy. Rozwarte ramiona symbolizują przecież wolną wolę (Libero arbitrio), gdyż rozkładają się na kształt litery Pitagorasa. Kawaler z Perugii objaśnia symbol w następujących słowach:

La lettera Greca Y si aggiugne allo scettro, per dinotare quella sententia di Pitagora Filosofo famoso con essa dichiarò che la vita humana haueua due vie, come la sopradetta lettera è diuisa in due rami, del quale il destro è come la via della vitrù, che da principio è angusta, \& erta: ma nella sommità è spatiosa, \& agiata, \& il ramo sinistro è come la strada del vitio, la quale è larga, \& commoda: ma sinisce in angustia, \& precipitij, si come molto bene spiegano i versi, i quali si attribuiscono à Virgilio ${ }^{19}$.

Pierwsze wydanie „Iconologii” ukazało się w Rzymie w 1593 r. ${ }^{20}$, wznowienie zaś w Mediolanie w 1602 r. W następnym roku wydrukowano pierwsze wydanie ilustrowane drzeworytami, znacznie obszerniejsze, uzupełnione w stosunku do edycji XVI-wiecznej. Czy El Greco wykorzystał w tym wypadku popularną już edycję z 1603 r., skoro podobne ujęcia świętego znane są sprzed daty publikacji? Zawarte $\mathrm{w}$ niej pojęcia emblematyczne, zapożyczone na ogół od autorów starożytnych a rozwinięte i wzbogacone w duchu katolickim, funkcjonowały wszakże powszechnie wśród wybitnych twórców i ich mecenasów, zanim zostały rozpropagowane przez ten bodaj najbardziej znany nowożytny słownik emblematyczny.

Przyjęte jak dotąd wczesne datowanie obrazu z Kosowa Lackiego na 1578-80 r. i uznanie go za jedno z najstarszych przedstawień św. Franciszka w twórczości malarza $^{21}$ - abstrahując od możliwej recepcji wymowy symbolicznej ze słownika Ripy - nie wydaje się zasadne. Nie jest także słuszne twierdzenie, jakoby dzieło to miało być pierwowzorem dla kolejnych przedstawień świętego zakonnika. Obraz odpowiada dojrzałemu stylowi pracy malarza. Pominięcie przezeń dosłownych elementów wizualizacyjnych na rzecz wyobrażeń domyślnych oraz zwrot ku chłodniejszym tonom palety, specyficzne użycie światła i charakterystyczny sposób przedstawienia niskich chmur na tle nieba w poświacie księżyca (a nie błyskawic!), rozwiewanych silnymi podmuchami wiatru, jaki osiągnął sugestywną głębię

19 Ibidem, s. 296-297: „Grecką literą ypsilon wieńczy się berło, aby uczynić aluzję do sentencji słynnego filozofa Pitagorasa, który objaśnił ją mówiąc, że wspomniana litera ma dwa ramiona: prawe to jakby droga cnoty, z początku wąska i stroma, na szczycie zaś rozległa i wygodna; natomiast lewe ramię to jakby droga występku, początkowo szeroka i dogodna, kończąca się jednak ścieżką podciętą urwiskiem; bardzo dobrze objaśniają to strofy przypisywane Wergiliuszowi:

Litera Pitagorasa o kształcie rozwidlonego rogu,

Wydaje się przedstawiać wzór ludzkiego życia.

20 Ripa 1593, s. 170 (Misericordia) oraz s. 150-151 (jedynie Liberta).

${ }^{21}$ Tak od 1974 r., por. Galicka, Sygietyńska 1974, s. 139. 
w słynnym „Widoku Toledo”22 (il. 6), skłania do przesunięcia datowania w kierunku dzieł późniejszych, nawet na początek XVII stulecia.

Wyobrażeniu z omawianego obrazu nie odpowiada określenie „ekstaza”, które łączone jest na ogół z upojeniem w transie. Określenia „widzenie” lub „wizja” są w tym wypadku nieadekwatne. Opisują rzeczywistość tylko w części. Precyzyjniejszym określeniem byłoby „doznanie”, „wzruszenie” bądź „rozrzewnienie” - jest to bowiem stan związany z dokonanym odkryciem - lub „admiracja”, gdy odnosi się do relacji świętego wobec Boga.

Termin „admiracja”, z łac. admiratio (podziw), odnosi się do uwielbienia i podziwu dla kogoś lub czegoś, i w tym sensie używany był w staropolszczyźnie. Określenie to odpowiada jednemu z przedstawień serii franciszkańskiej El Greca, które funkcjonują pod mianem „ekstaza”. „Admiracja” wydaje się właściwsza niż bliskoznaczne „adoracja” lub „cześć”.

Jedną z serii typologicznych przedstawień El Greca jest „Św. Franciszek otrzymujący stygmaty". Rany były wprawdzie wyraźne na dłoniach świętego z podlaskiego obrazu już w chwili odkrycia, zwłaszcza na dłoni prawej oraz na habicie w okolicy serca (il. 4), jednak nie były widoczne promienie łączące je z poświatą nieba lub wyobrażeniem Chrystusa serafickiego na Krzyżu, jak w podobnym ujęciu postaci z kolekcji Juana Abelló Gallo w Madrycie (il. 7) ${ }^{23}$, które jednoznacznie określiłyby charakter przedstawienia. To właśnie te linie oraz charakter ran mają zasadnicze znaczenie dla ustalenia wymowy. Zwrócić uwagę należy, że w wypadku przedstawienia z Museo Cerralbo, któremu nadano nazwę „Stygmatyzacja" ${ }^{24}$, święty nie ma jeszcze mistycznych ran Męki Pańskiej (il. 8), a boska obecność została zaakcentowana jedynie w postaci rozświetlonego nieba. Obrazowi ze Szpitala Matki Boskiej z Carmen w Kadyksie o identycznej kompozycji, a różniącym się detalami i występowaniem stygmatów na dłoni, nadano zaś nazwę „Wizja św. Franciszka” (il. 9) ${ }^{25}$. Natomiast w przedstawieniu z Walters Art Gallery w Baltimore (il. 10), nazwanym „Stygmatyzacja św. Franciszka”26, jest pewna nieścisłość. Doznaje on widzenia, którym jest zaskoczony, o czym przekonuje układ jego dłoni, lecz widoczny na lewym śródręczu otrzymany stygmat ma ranę zasklepioną skrzepliną, tak jakby zdarzenie miało miejsce wcześniej. Analogiczną sytuację mamy w wypadku przedstawienia św. Franciszka z Museo Lázaro

${ }^{22}$ Nowy Jork, Metropolitan Museum of Art, 29.100.6. Olej na płótnie: $121 \times 108$ cm, ok. 15991600.

${ }^{23}$ Madryt, Colección Abelló. Olej na płótnie: $108 \times 83$ cm, ok. 1580 .

${ }^{24}$ Madryt, Museo Cerralbo, 1982. Olej na płótnie: $194 \times 150$, cm, ok. 1600-1605.

${ }^{25}$ Kadyks, Hospital de Mujeres y Capilla de Nuestra Señora del Carmen. Olej na płótnie: $203 \times$ $148 \mathrm{~cm}$, ok. 1600-1605. St. Francis's Vision of the Flaming Torch.

${ }^{26}$ Baltimore, Walters Art Gallery, 37.424. Olej na płótnie: $102 \times 97$ cm, ok. 1585-90. 


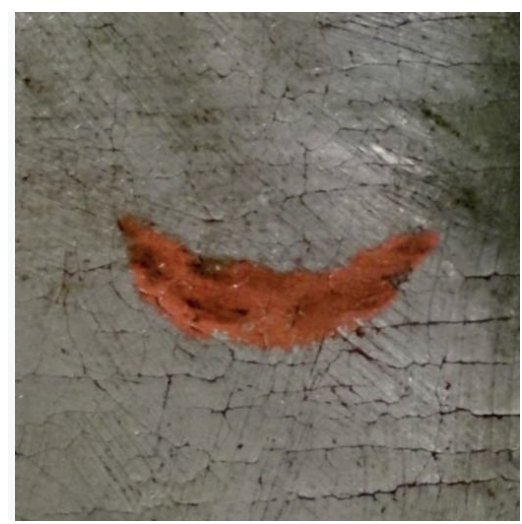

4. Stygmat na habicie zakonnika - element nieautorski, usunięty w 2016 r. Fot. autor.
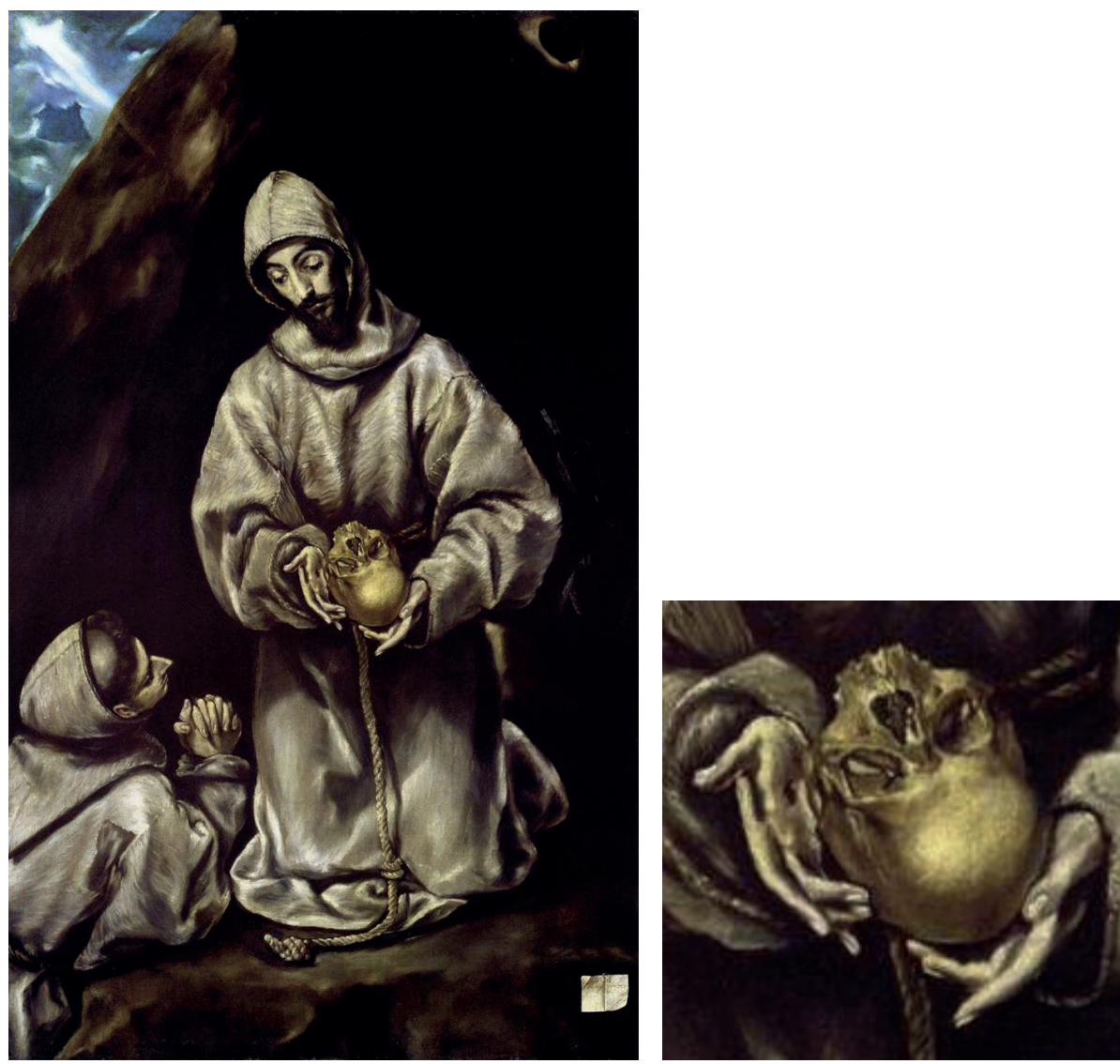

5. El Greco, Św. Franciszek i brat Leon rozmyślają o śmierci. Ottawa [online]. National Gallery of Canada, domena publiczna [dostęp: 2021-06-19]. Dostępny w Internecie: <El_Greco_-_St_ Francis_and_Brother_Leo_Meditating_on_Death_-_WGA10560.jpg > 


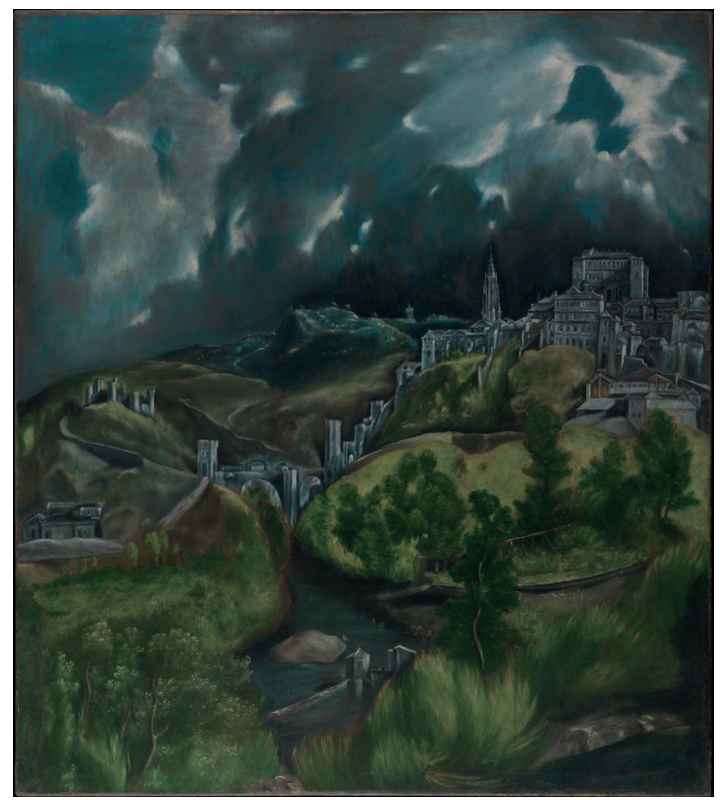

6. El Greco, Widok Toledo [online]. Nowy Jork, Metropolitan Museum of Art [dostęp: 2021-03-25]. Dostępny w Internecie: <https://www.metmuseum.org/ art/collection/search/436575>
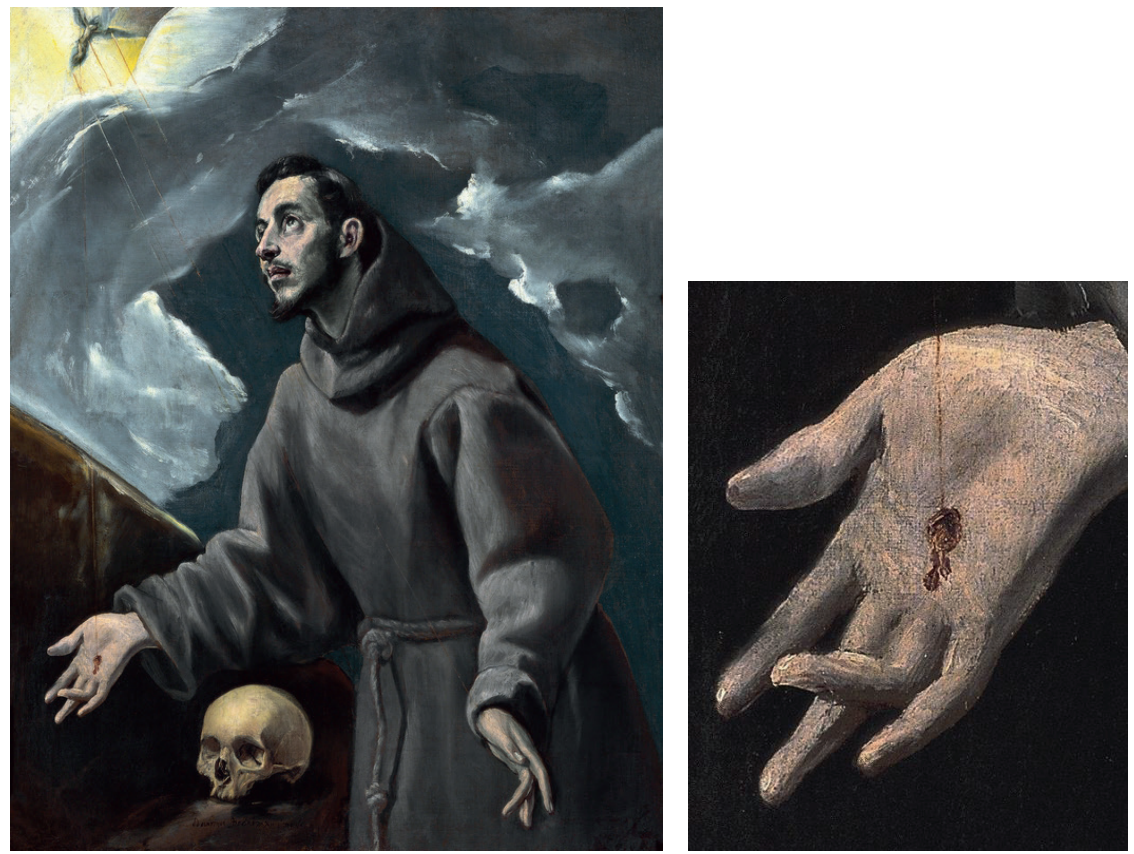

7. El Greco, Stygmatyzacja św. Franciszka. Madryt, Colección Abelló (zb. pryw.) [online]. Alain R. Truong [dostęp: 2021-03-25]. Dostępny w Internecie: <http://www.alaintruong. com/archives/2015/04/20/31919314.html> 

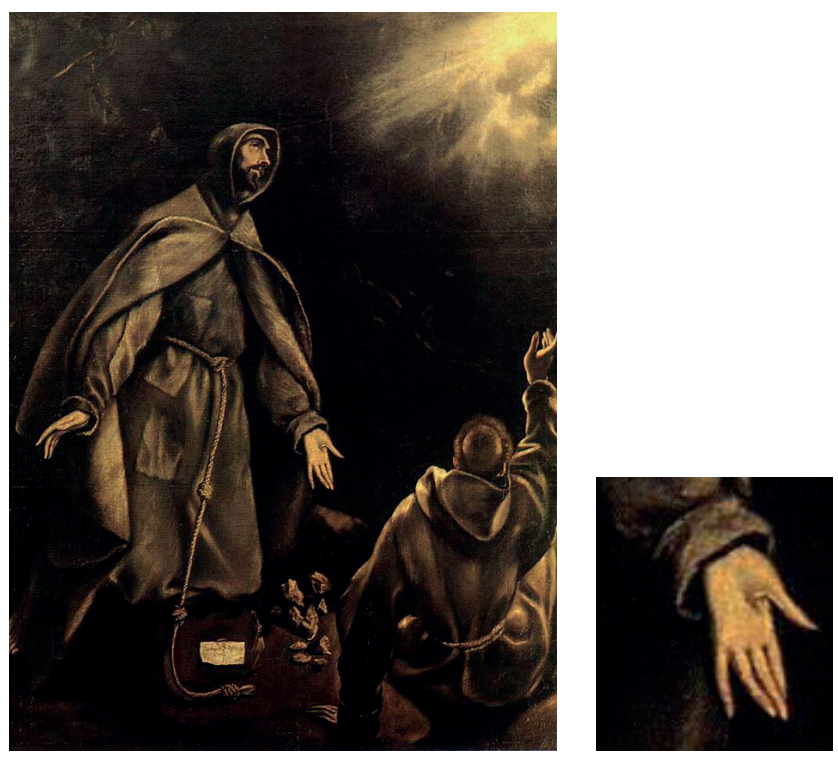

8. El Greco, Wizja św. Franciszka, zw. dotychczas Stygmatyzacja św. Franciszka. Madryt, Museo Cerralbo [online]. Wikipedia [dostęp: 2021-03-25]. Dostępny w Internecie: <https://www.wikiart.org/ en/el-greco/stigmatisation-of-st-francis>
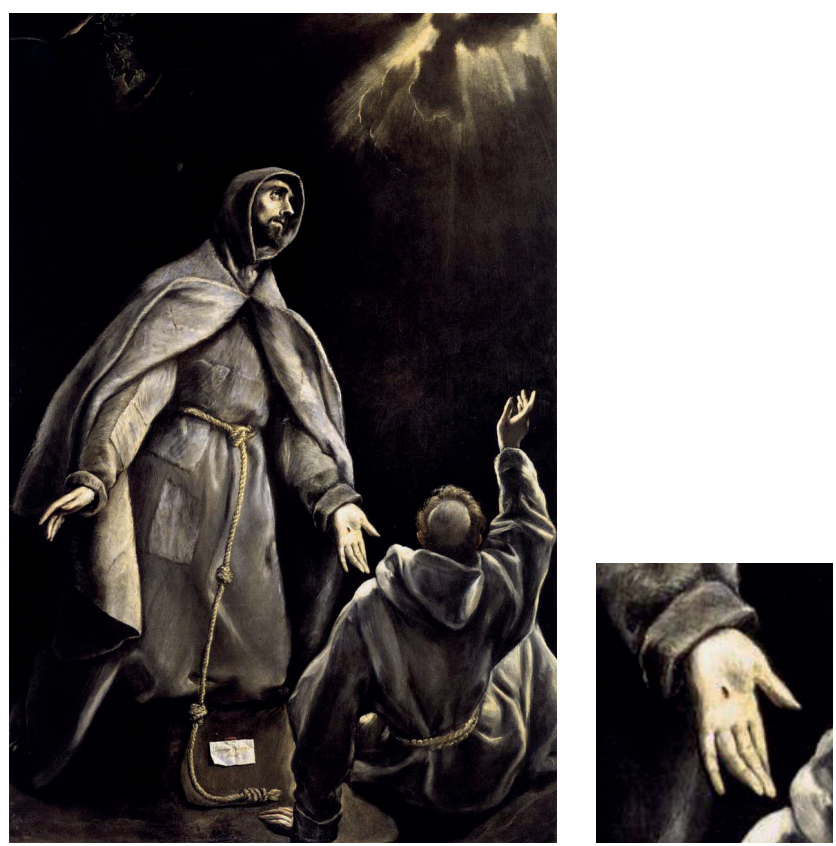

9. El Greco, Wizja św. Franciszka. Kadyks, Hospital de Mujeres y Capilla de Nuestra Señora del Carmen [online]. Wikipedia [dostęp: 2021-03-25]. Dostępny w Internecie: <https://pl.wikipedia.org/ wiki/Plik:El_Greco_-_St_Francis\%27s_Vision_of_the_Flaming_Torch_-_WGA10561.jpg> 

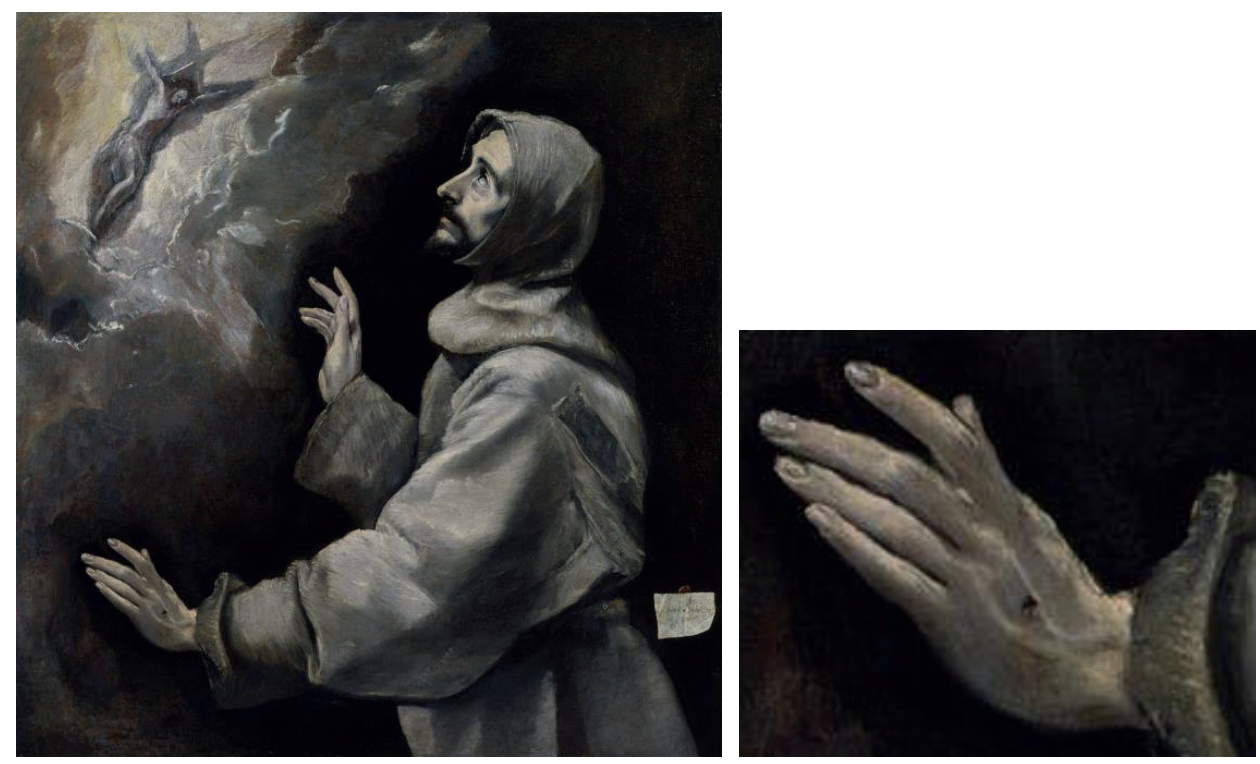

10. El Greco, Wizja św. Franciszka, zw. dotychczas Św. Franciszek otrzymujący stygmaty. Baltimore, Walters Art Gallery [online]. Wikipedia [dostęp: 2021-03-25]. Dostępny w Internecie: <https:// commons.wikimedia.org/wiki/File:El_Greco_-_Saint_Francis_Receiving_the_Stigmata_-_Walters_37424.jpg>

Galdiano w Madrycie (il. 11) ${ }^{27}$. Tu także otoczenie rany ma cechę zakrzepłej krwi. Wyobrażony gest przeczy zaś stanowi ekstazy. Dla tych płócien bardziej zasadne wydaje się określenie „wizja”, a nawet „zaskoczenie wizją”, oraz „oddanie się Bogu” - zwłaszcza z uwagi na charakterystyczne gesty dłoni na pierwszym obrazie i sposób złożenia ramion na drugim.

Dotąd w literaturze przedmiotu nie zwrócono uwagi na charakter przedstawienia ran stygmatycznych i nie wyciągnięto wniosków z układu palców. Rana na prawej dłoni w „Stygmatyzacji św. Franciszka” z kolekcji Abelló jest świeża. Strużka krwi spływa wzdłuż dłoni. Widoczne są też czerwone promienie boskiej mocy przekazujące stygmaty świętemu. Przyjęta nazwa jest w tym wypadku całkowicie zasadna. Dopuszczalne jest też nazewnictwo przedstawienia z Museo Cerralbo, za którym przemawia obecny na płótnie współbrat Leon, towarzysz świętego na górze La Verna, choć w rzeczywistości nie był on świadkiem zdarzenia. W tym wypadku El Greco wyobraził początkowy moment mistycznego objawienia, na chwilę przed otrzymaniem zaszczytnego daru. Jednak dla tego dzieła niewątpliwie precyzyjniejszym określeniem byłaby „Wizja św. Franciszka”. Stygmatyzację wyraża natomiast także charakterystyczny układ palców. Otóż uraz spowodo-

${ }^{27}$ Madryt, Museo Lázaro Galdiano, 02148. Olej na płótnie: $89 \times 57$ cm, 1577-1580. 

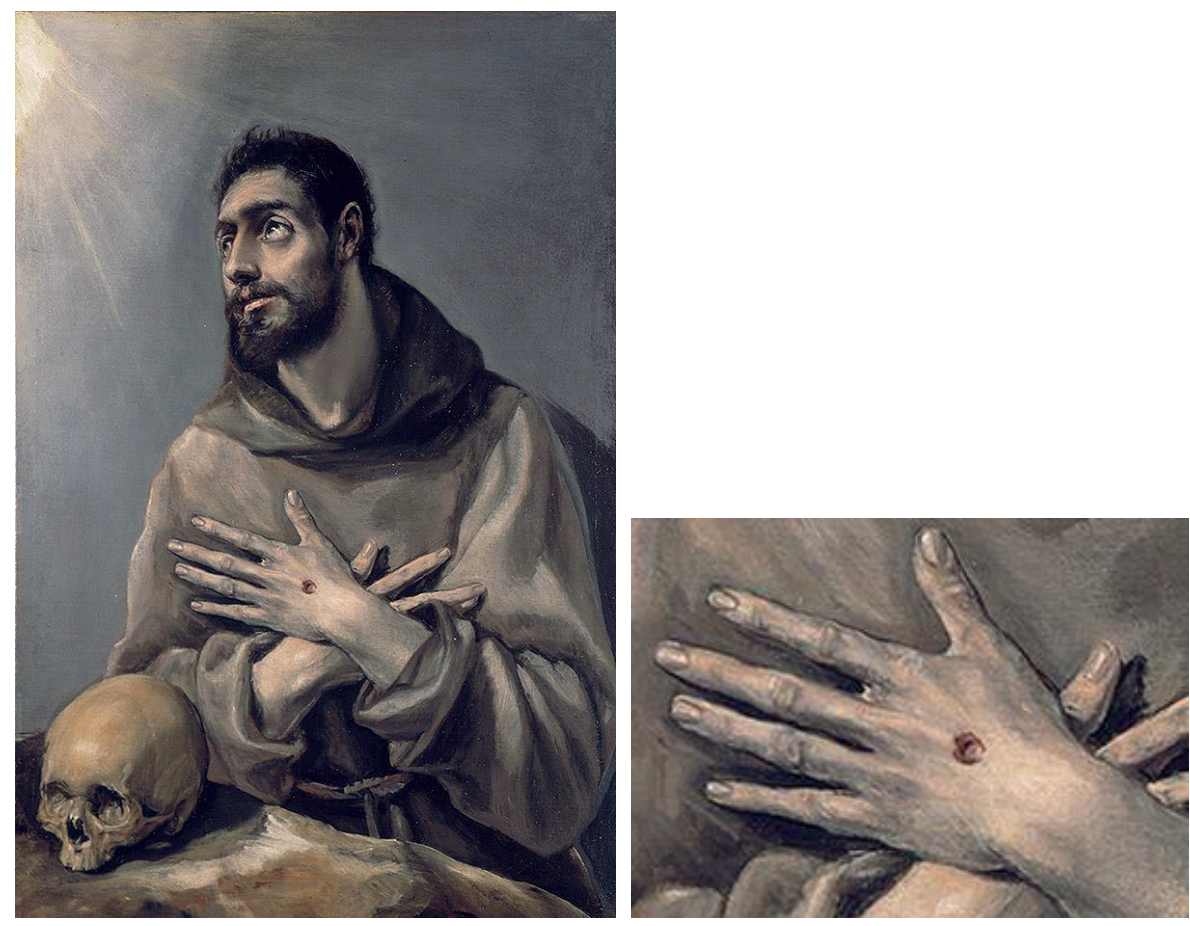

11. El Greco, Św. Franciszek oddaje się Bogu, zw. dotychczas Św. Franciszek w ekstazie; Madryt [online]. Museo Lázaro Galdiano [dostęp: 2021-03-25]. Dostępny w Internecie: <http://www. flg.es/elgreco-d-theotocopuli>

wany przebiciem śródręcza uszkadza nerwy dłoniowe, powodując mimowolny skurcz palców oraz niedokrwienne przykurcze. Dlatego też w przedstawieniach „Stygmatyzacji św. Franciszka” El Greca palce - środkowy i serdeczny - zagięte są do wnętrza dłoni. Szczególnie jest to wyraziste na obrazie z Colección Abelló. W niektórych wypadkach mamy jednak do czynienia z manierą malarza i zgięcie palców - ale mniej wyraźne - nie jest związane ze stygmatyzacją. Wszystkie rany w przedstawieniach św. Franciszka mają kształt owalny lub czworoboczny, o średnicy około jednego centymetra, odpowiadającej przekrojowi gwoździ rzymskich stosowanych do krucyfikacji. Tradycja przedstawień takich ran znana była od średniowiecza, co wyraziście oddał Bramantino (Bartolomeo Suardi), uczeń dociekliwego Leonarda da Vinci, w obrazie „Chrystus Zmartwychwstały” (Cristo resucitado) z ok. 1490 r. (il. 12) ${ }^{28}$.

Na obrazie z Muzeum Diecezjalnego w Siedlcach palce obu dłoni nie są zagięte do wnętrza. Rany nie sprawiają wrażenia ani świeżych lub odnawiających się,

${ }^{28}$ Madryt, Museo Thyssen-Bornemisza, 61 (1937.1). Technika mieszana na panelu: 73,0 × 109,0 cm, ok. 1490. Zob. Barobia 2009, s. 158-159. 

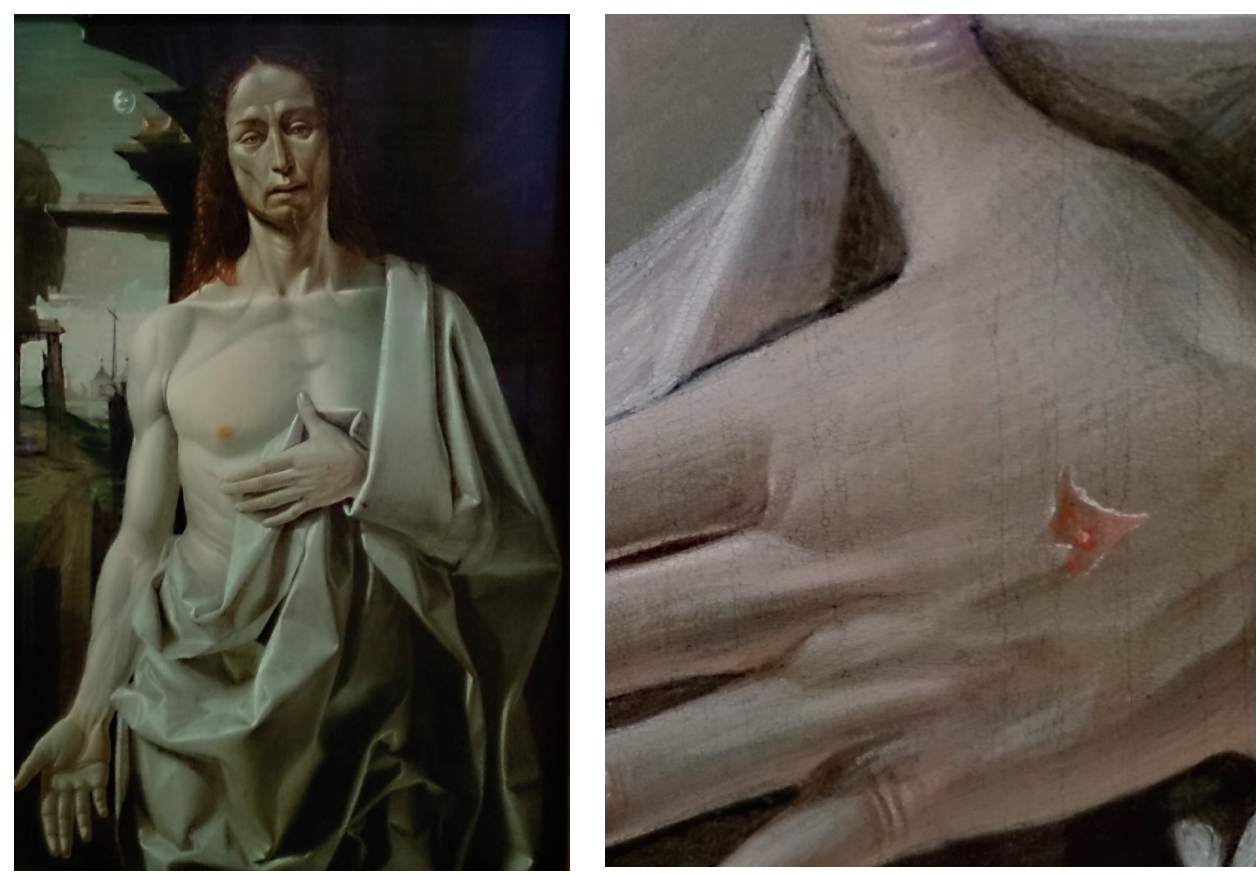

12. Bramantino, Chrystus Zmartwychwstały, Madryt, Museo Thyssen-Bornemisza. Fot. autor.

ani zasklepionych. Są podłużne. Spostrzeżenie to prowadzi do wniosku, że nie są dziełem El Greca. Jako dodatek wtórny powinny zostać usunięte, ponieważ zmieniają zasadniczo wymowę przedstawienia. W tej sytuacji nie można przyjąć, że św. Franciszek wyobrażony został w momencie stygmatyzacji.

Wymowę ikonograficzną potwierdzają obecne odkrycia. Podczas ostatnich prac konserwatorskich, przeprowadzonych w 2016 r. w Pracowni Konserwacji Malarstwa i Rzeźby Muzeum Narodowego w Krakowie ${ }^{29}$, okazało się, że stygmat w okolicy serca został domalowany bez udziału El Greca, i to w okresie znacznie późniejszym, dlatego został zdjęty ${ }^{30}$. Nie usunięto jednak stygmatów na dłoniach, chociaż analiza składu pigmentów i położenia na wcześniejszym werniksie dowiodły nieautorskiego ich pochodzenia. Dostrzeżone wówczas czerwone linie wyobrażające promienie, uprzednio niewidoczne wskutek przemalowań i postarzenia warstwy malarskiej, nie zostały przywrócone. Stanowiły one także późniejszy

${ }^{29}$ Zob. El Greco 2017, film dokumentalny. Na marginesie wypada zaznaczyć, że wykonana wówczas nowa rama mikroklimatyczna jest zbyt ozdobna. Listwa wewnętrzna w stosunku do zewnętrznej jest za bardzo masywna. Złocenie przesadnie wyraziste. Dekoracja zaś w polach narożnych ramy, zapożyczona z ram znanych z kilku dzieł eksponowanych w Museo de Santa Cruz w Toledo, rozprasza skupienie widza na dziele zasadniczym. Nowa rama zmieniła tonację kolorystyczną obrazu, przesuwając ją w kierunku barw ciepłych. Zob. sekwencja filmu 10:20-10:30 oraz 10:43-10:46.

${ }^{30}$ Najwcześniej został dodany na początku XIX w. Zob.: Czop, Frączek i Zygier 2016. 
wtręt. Linii stygmalnych nie odtworzono, co było zasadne w sytuacji dodatku nieautorskiego, jednak pozostawienie stygmatów na dłoniach okazało się alogiczne. W twórczości El Greca dłonie św. Franciszka były malowane bez stygmatów lub ze stygmatami, ale nie zawsze wraz z liniami świetlnymi, jak na obrazie z Museo de Santa Cruz w Toledo ${ }^{31}$ (il. 13). W sytuacji jednoznacznego rozpoznania, że są one późniejsze, nie powinny zostać zachowane tylko z uwagi na nawiązanie do tradycji większości przedstawień malarskich. Jeżeli zaś stygmaty te były położone na pierwotnych, to też powinny zostać zdjęte w celu odsłonięcia oryginalnych bądź odtworzenia właściwego kształtu, jeśli dawne pigmenty straciły czytelność. Nie stwierdzono natomiast wyobrażenia Chrystusa serafickiego na Krzyżu w warstwach poświaty, który znany był z innych obrazów serii franciszkańskiej El Greca.
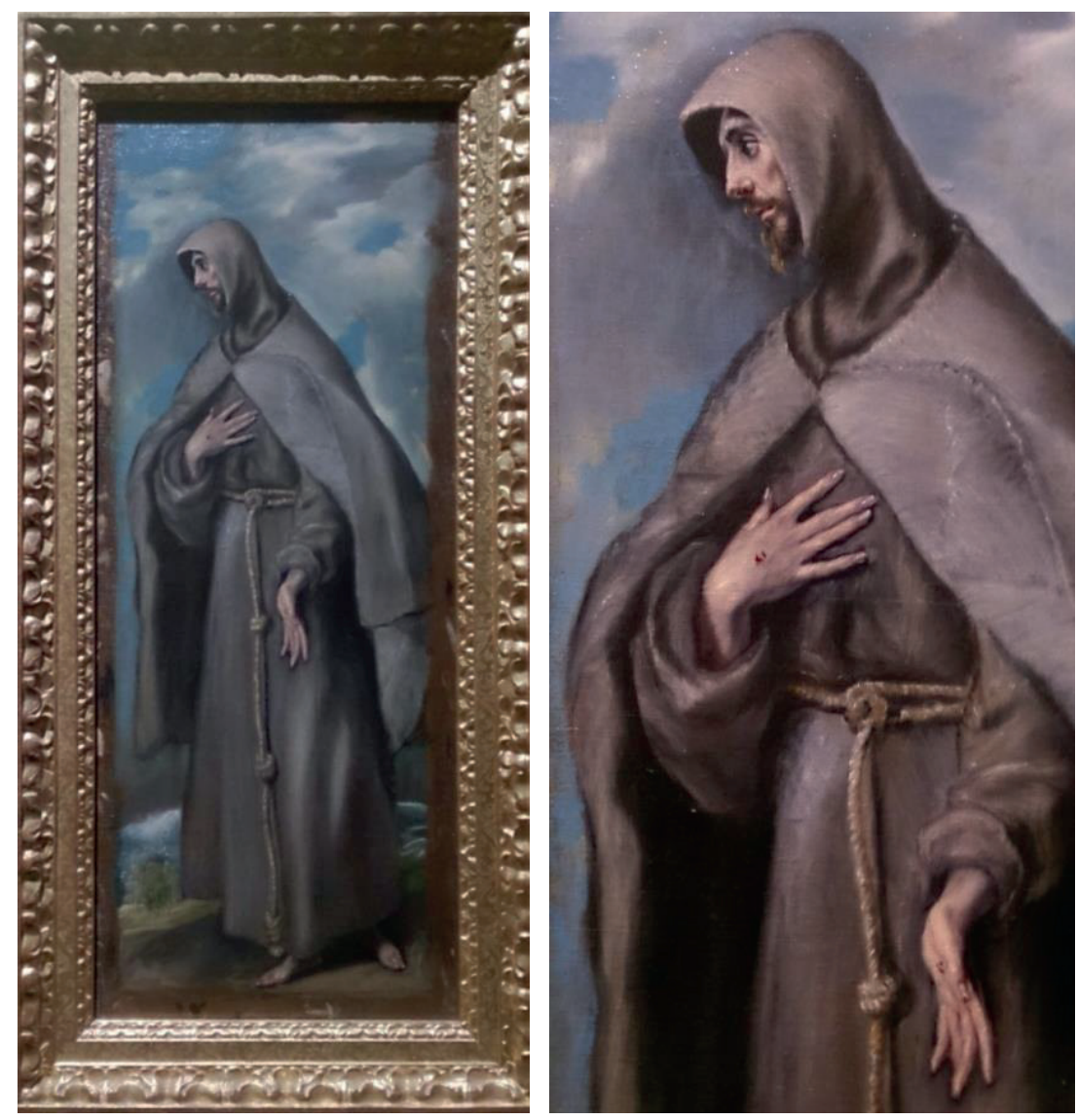

13. El Greco, Św. Franciszek, Toledo, Museo de Santa Cruz. Fot. autor.

${ }^{31}$ Toledo, Museo de Santa Cruz, DO1278. Olej na płótnie 56,0 × 138,0 cm, ok. 1595-1600. 
O tym, czy mamy do czynienia ze stygmatyzacją, czy też z innym stanem duchowym, decydują linie stygmalne i charakter ran stygmatycznych lub ich brak oraz układ palców, w mniejszym zaś stopniu wyobrażenie Ukrzyżowanego w rozświetlonej części nieba. Te elementy obrazu mogły z jednej strony zostać usunięte $\mathrm{w}$ trakcie intencjonalnych przemalowań czy też niewłaściwie przeprowadzonych konserwacji, $\mathrm{z}$ drugiej zaś zostać dodane $\mathrm{z}$ uwagi na wymowę. Tak więc ustalenie właściwego nazewnictwa wymaga uprzedniego wyeliminowania wszelkich niejasności związanych z oceną pierwotnego stanu płótna.

Reasumując - termin „ekstaza” nie oddaje należycie stanu duchowego przedstawionej postaci. Dla pierwotnego wyobrażenia, nieuwzględniającego szeregu istotnych detali łączonych ze stygmatyzacją, właściwsze jest określenie „admiracja”, szczególnie w konteście relacji świętego wobec Boga. Najbardziej odpowiada ono stanowi ducha zakonnika głęboko przeżywającego bliskość Stwórcy. Korespondują z nim pojęcia miłosiernego wzruszenia oraz wstawiennictwa, dookreślające sytuację, w której św. Franciszek wyprasza Boskiego zmiłowania dla nieznanego mu człowieka, którego szczątki kostne przypadkowo odnalazł. Propozycja korekty wydaje się zasadna. $\mathrm{W}$ przeciwnym razie dotychczasowa nazwa utrwali się, petryfikując nieścisłość określenia.

Pierwotna nazwa obrazu z madryckiego Museo Cerralbo „Stygmatyzacja św. Franciszka” nie odpowiadała przedstawieniu. W tym wypadku właściwa jest „Wizja św. Franciszka”. Wynika to z faktu, że święty nie ma na dłoniach stygmatów. Identyczną scenę pokazuje „Wizja św. Franciszka” z Hospital de Mujeres y Capilla de Nuestra Señora del Carmen w Kadyksie. Mimo że na dłoniach są stygmaty, brakuje linii świetlnych jak w „Stygmatyzacji św. Franciszka” z Colección Abelló w Madrycie. Brak tychże stanowi argument decydujący przy określeniu wymowy dzieła. Obraz z Walters Art Gallery w Baltimore zwany „Św. Franciszek otrzymujący stygmaty”, podobnie jak w powyższym wypadku, jest w istocie „Wizją św. Franciszka”. Natomiast „Św. Franciszek w ekstazie” z dzieła w Museo Lázaro Galdiano w Madrycie to w istocie „Św. Franciszek oddający się Bogu”.

\section{ECSTASY OR ADMIRATION? ICONOGRAPHY OF THE PAINTING OF ST. FRANCIS FROM THE DIOCESAN MUSEUM IN SIEDLCE IN THE SEMIOTIC CONTEXT OF SELECTED WORKS FROM EL GRECO'S FRANCISCAN SERIES}

\section{Summary}

The painting by El Greco at the Diocesan Museum in Siedlce was discovered in 1964, and it is now widely referred to as "Ecstasy of St Francis" (Fig. 1). The appellation was not used in the very first publication of 1965, having been introduced in the subsequent text from 1966, based on the typology developed four years previously by José Gudiol. The latter distinguished 13 iconographic types in the Franciscan series by the Toledan master and called one of those "Ecstasy of St. Francis". Once used, 
the term persisted. Thus far, the significance and the meaning of the name has not been confronted with an analysis of the representation, especially considering current knowledge about its details.

Ecstasy, from the Old Greek है $\kappa \sigma \tau \alpha \sigma \iota \varsigma$ (being outside of oneself), is an ambiguous term today as it departs from the original etymology. Although it may also be understood as a mystical egress of the soul from the body in the unique moment of unity with God, it is still generally associated with the depth of mental and physical experience during which a person has a limited capacity to perceive external sensory stimuli. In particular, the notion of ecstasy connotes a state of being in a trance and irrational action. This does not appear to apply to the representations of St Francis in the paintings by $\mathrm{El} \mathrm{Greco,} \mathrm{if} \mathrm{only} \mathrm{for} \mathrm{the} \mathrm{reason} \mathrm{that} \mathrm{despite} \mathrm{the} \mathrm{mystical} \mathrm{experience,} \mathrm{the} \mathrm{reactions} \mathrm{of} \mathrm{the} \mathrm{protagonist}$ are rational.

St Francis' facial expression in the painting at the Diocesan Museum in Siedlce is focused and solemn, the figure static and virtually statuesque, without a single element of the ecstatic elation. The gaze directed upwards and the watery left eye with a teardrop hanging from the lower eyelid (Fig. 2) do not provide sufficient grounds to use the term "ecstasy". The tears welling up are not the effect of the growing pain of the stigmata but result from the adoration of God, from the reason of reflection on the nature of all things. The direction of the gaze and its character express the conviction of the love of the Creator to the human, which is reciprocated by the saint. At the same time, it attests to the awareness of his own insignificance, the frailty of earthly existence and compassion for the fellow brethren. This is evinced by the skull - a symbol of vanitas - the key and essential detail of the representation (Fig. 3). In its immediate proximity, the painter depicted fragmented bone remains, using schematic brighter blots on a darker background. It is upon discovering them that St Francis spreads his arms, raising his eyes to the heavens. The motif departs from most previous representations, which only feature the skull alone, resting on a boulder. Here it seems to be situated near the original site of discovery, which may have occurred due to erosion of soil on the slope of the hill. Its lower jaw is missing. The bones of the jaw are clearly damaged, just as the rim of the nasal cavity and the septum.

A popular composition which is ideologically related to the above detail is a scene depicting meditation on death during a retreat in the mountains, found e.g. in "San Francisco de Asís y el hermano León meditando sobre la Muerte" (Fig. 5). In the latter, El Greco is represented in one of the most striking and original scenes, whose transcendental dimension is in the secret of the human soul. Kneeling at the mouth of a cave, Francis is gently holding a skull, while a fellow friar is looking at it in concentration, his hands clasped in prayer. In the background the slope of the hillock makes one realize certain circumstances, and encourages one to complete the story of the moment preceding the meditation. There can be no doubt that the discovery was accidental. The strolling monks reached the entrance to the cave where they found the human remains, exposed due to erosion as the soil subsided; alternatively, the bones may have been dug out from the original burial in the cave by wild animals. It is unlikely that the monks brought a skull to such a scenery for the purpose of meditation. A stigma can be seen on the hand of St Francis, though it is not directly related to the adoration of God at that moment, i.e. with the represented scene.

The place where the monk looks towards cannot be discerned in the painting from Kosowo. At any rate, his gaze in not directed to the illuminated clouds in the upper left corner, as they are situated above the right temple of the saint, and thus cannot constitute a point of reference. St Francis communes with the Absolute looking into the distance, somewhere beyond the pictorial field. The viewer is to experience no more that this and as much as this, which is an effect intended by the painter. The warm glow in the upper left corner against the cold sky manifests the divine presence that the saint 
witnesses, but the viewer is not given that chance. The glow is the edge of the radiance emanating from the Most High. St Francis spreads his arms, palms outwards, in a gesture of surrendering to God, venerating him, but also in a gesture of commiseration over the remains of a human he has come across. The open arms have their specific symbolic significance as well. It is a sign of Compassion (Misericordia) in Cesare Ripa's "Iconologia". St Francis is not indifferent to the find, as he does not leave the remains merely as they were but turns to the Creator. After all, his open arms symbolize free will (libero arbitrio) follow the shape of Pythagoras' letter, to which Ripa also refers. This is the message expressed in the painting and conveyed to the viewer by the painter.

The painting was dated quite early, i.e. to 1578-80. Regardless of the possible perception of the symbols based on Ripa's dictionary - the 1603 edition - it does not seem justified. The work corresponds with the mature style of the painter. Given the absence of literal elements of visualization in favour of the implied, the colder palette, the peculiar use of light and the characteristic manner of depicting low clouds against the sky, illuminated by the glow of the moon (as opposed to lightning), driven by a strong gust of the wind that was so suggestive in the famed "View of Toledo" from the Metropolitan Museum of Art (Fig. 6), warrants dating the piece among the later works, perhaps as late as the early seventeenth century.

The representation does not tally with the designation of ecstasy, which is usually associated with an exhilarated trance, as observed above. It would be more precise to use terms such as "sensation", "emotion" or "tenderness" to describe the state following the discover, or "admiration" to render the relationship of the saint with God. Latin admiratio denotes veneration and admiration of a person, and corresponds with one of the representation in the El Greco's Franciscan series, which function as "ecstasy".

Also, authors have so far failed to notice the character of the represented stigmata, and no conclusions have been drawn from the arrangement of the fingers. The wound on the right hand in "The Stigmatization of St Francis" from Juan Abellós collection in Madrid is fresh (Fig. 7), with a trickle of blood running down the palm. There is also red radiance coming from the wounds of Christ Seraphim on the Cross, which transfer the stigmata to the saint. In this case, the adopted title is by all means legitimate. The characteristic placement of the fingers also speaks in favour of stigmatization. The injury caused by piercing the palm damages the nerves of the hand resulting in uncontrollable finger spasm and ischaemic contracture. This is why in the depictions of "Stigmatization of St Francis" by El Greco the middle and the ring fingers are curled inwards, which is particularly vivid in this painting. However, in some cases the manner of the painter comes to the fore and the bending of the fingers - less distinctive - Is not associated with stigmatization. All wounds in the portrayals of St Francis are oval or four-sided, with a diameter of roughly $1 \mathrm{~cm}$, which corresponds with the profile of the Roman nails used in crucifixion. The tradition of representing such injuries had been known since the Middle Ages, which is graphically shown by Bramantino (Bartolomeo Suardi), a disciple of the inquisitive Leonardo da Vinci, in "Cristo resucitado" (risorto) from approximately 1490 (Fig. 12).

In the case of the representation from the Museo Cerralbo, known as "Stigmatization" (Fig. 8), the saint does not yet have the mystical wounds of the Passion, while the divine presence is indicated only by the illuminated sky. The painting from the Hospital de Mujeres y Capilla de Nuestra Señora del Carmen in Cadiz demonstrates identical composition but differs in detail and presence of the stigmata, and the title it now bears is "St Francis's Vision" (Fig. 9). On the other hand, in the painting held at the Walters Art Gallery in Baltimore, called "Stigmatization of St Francis" (Fig. 10), there is a certain inconsistency. The protagonist experiences a vision - which surprises him - as the arrangement of his hands indicates, but the stigma on his left palm is closed, covered by clotted blood, as if it 
happened earlier. Much the same applies to the depiction of St Francis from Museo Lázaro Galdiano in Madrid (Fig. 11), where the wound appears to be surrounded by clotted blood, while the represented gesture does not tally with the notion of ecstasy.

In the painting at the Diocesan Museum in Siedlce, the fingers of both hands are not bent towards the palms, the wounds do not give the impression of being fresh, reopened or healed, while their shape is elongated. This detail leads to the conclusion that they were not painted by El Greco. As a secondary addition, they should be removed since they essentially change the substance of the representation. In this situation, it cannot be presumed that St Francis was depicted in the moment of stigmatization, which was confirmed by the recent conservation conducted in 2016 in Krakow. It turned out at the time that the stigma near the heart was painted in without El Greco's contribution, in a much later period (Fig. 4), which is why it was removed. No such procedure was applied to the stigmata on the hands, even though the analysis of pigment composition and their placement on earlier varnish prove that they did not originate with the author. Also, presence of red lines of stigmal radiance was determined, but no reconstruction was performed; this was justified with respect to an addition that had not been made by the author, but leaving the stigmata on the hands seems illogical in the circumstances. In a number of El Greco's works the hands of St Francis were painted without as well as with stigmata, though they were not always accompanied by the rays of light, as in the painting from the Museo de Santa Cruz in Toledo (Fig. 13). Having established that the stigmata are a later element, they should not be retained solely because of reference to the tradition of most painterly representations. If they happen to have been painted on the originals, they should be removed as well to reveal the original or have the opportunity to reconstruct them if the earlier pigments faded.

Whether one is dealing with stigmatization or a different spiritual state is determined by the stigmal lines and the nature of the stigmatic wounds - or their absence - as well as the arrangements of the fingers; the representation of the crucified God in the illuminated section of the sky is also relevant, though to a lesser degree. Thus, if a correct appellation is to be established, the unclear aspects relating to the assessment of the original state of the painting should be resolved beforehand.

The erstwhile name of the painting from the Museo Cerralbo in Madrid, i.e. "Stigmatization of St. Francis", did not correspond to the representation, and the subsequent "Vision of St Francis" is correct in that case, given that the saint's hands feature no stigmata. An identical scene is found in "St Francis's Vision" at the Hospital de Mujeres y Capilla de Nuestra Señora del Carmen in Cadiz; the hands bear the stigmata, but the rays of light - like those in "Stigmatization of St Francis" from the Colección Abelló in Madrid - are absent. The lack of such lines is a decisive argument when the characteristics of the work are defined. The painting at the Walters Art Gallery in Baltimore, described as "Saint Francis of Assisi Receiving the Stigmata" is, just as the above case, a "Vision of Francis", whereas "St Francis in Ecstasy" at the Museo Lázaro Galdiano in Madrid is, considering its substance, "St Francis Devoting Himself to God".

\section{Bibliografia - źródła i opracowania}

Barobia M. 2009, Museo Thyssen-Bornemisza: Old Masters, Madrid.

Cuesta J.R. 2016, Una nueva propuesta catalográfica para la producción seriada del Greco: principios teóricos para un nuevo catálogo rozonado, [w:] E. Almarcha, P. Martínez-Burgos, E. Sainz (red.), El Greco en su IV Centenerio: Patrimonio hispánico y diálogo intercultural, Toledo.

Czop J., Frączek P., Zygier E. 2016, Dokumentacja konserwatorska dotycząca obrazu El Greco „Ekstaza św. Franciszka” z Muzeum Diecezjalnego w Siedlcach, Muzeum Narodowe w Krakowie. 
El Greco 2017, El Greco Ekstaza św. Franciszka, film dokumentalny [online]. Muzeum Narodowe w Krakowie [dostęp: 2021-03-25]. Dostępny w Internecie: <https://www.youtube.com/ watch?v=OATNugjjTeA $>$.

Galicka I., Sygietyńska H. 1966, Nieznany obraz w Kosowie z serii franciszkańskiej El Greca, Biuletyn Historii Sztuki 3/4.

Galicka I., Sygietyńska H. 1974, Obraz św. Franciszka z Kosowa - dziełem El Greca, Biuletyn Historii Sztuki XXXVI, 2.

Galicka I., Sygietyńska H. 2005, W sprawie listu Witalisa Wolnego, Biuletyn Historii Sztuki 1-2.

Galicka I., Sygietyńska H. 2006, Ein unbekannter Heiliger Franziskus in Ekstase des El Greco in Polen, Artibus et historiae an art anthology 54 (XXVII).

Grabski J. 2016, The Iconography of St. Francis in the Work of El Greco and His Workshop: Typology, Variants, Derivatives, [w:] A. Witko (red.), Art in the Time of El Greco, Kraków.

Gudiol J. 1962, Iconography and chronology in El Greco's paintings of St. Francis, The Art Bulletin XLIV: September, 3.

Katalog zabytków sztuki w Polsce 1965, Katalog zabytków sztuki w Polsce, X: Województwo warszawskie, red. I. Galicka, H. Sygietyńska, 25: Powiat sokołowski, Warszawa.

Mirończuk R. 2014a, Arcydzieło El Greca Ekstaza św. Franciszka, Teologiczne Studia Siedleckie XI, 11. Mirończuk R. 2014b, O obrazie Ekstaza świętego Franciszka El Greca, [w:] El Greco. Ekstaza świętego Franciszka z Muzeum Diecezjalnego w Siedlcach (Publikacja towarzysząca wystawie na Zamku Królewskim w Warszawie w dniach 16 września - 31 października 2014 r.), Warszawa.

Ripa C. 1593, Iconologia overo Descrittione dell' Imagini vniversali cavate dall'antichita Et da altri lvoghi Da Cesare Ripa Perugino. Opera non meno vtile, che necessaria à Poeti, Pittori, \& Scultori, per rappresentare le uirtù, uitij, affetti, \& passioni humane. In Roma. Per gli Heredi di Gio. Gigliotti. M. D. XCIII. Con Priuilegio. Et con Licenza de'Superiori, Rzym.

Ripa C. 1603, Iconologia overo Descrittione di diverse Imagini cauate dall'antichità, \& di propria inuentione, Trouate, \& dichiarate da Cesare Ripa Pervgino, Caualiere de Santi Mauritio, \& Lazaro. Di nuouo reuista, \& dal medesimo ampliata di 400. \& più Imagini, Et di Figure d intaglio adornata. Opera Non meno vtile che necessaria a Poeti, Pittori, Scultori, \& altri, per rappresentare le Virtù, Vitij, Affetti, \& Passioni humane. In Roma, Appresso Lepido Facij. M. DC. III. Con Licentia De'Svperiori, Rzym (adres wydawniczy także w kolofonie).

Ruiz-Gómez L. 2007, El Greco en el Museo Nacional del Prado, Madrid.

Słownik języka polskiego 1965, II: D-G, red. W. Doroszewski, S. Skorupka, Warszawa.

Słownik wyrazów obcych, wydanie nowe 1997, red. E. Sobol, Warszawa.

Skorupka S. 1985, Słownik frazeologiczny języka polskiego: A-P, Warszawa.

Wethey H.E. 1962, El Greco and His School, Princeton.

Wielki słownik wyrazów obcych 2008, red. A. Latuska, Kraków.

Wolny W. 2004, Jak było z odkryciem El Greca w Kosowie Lackim, Biuletyn Historii Sztuki 3-4. 